\title{
A qualidade do atendimento e suas influências no relacionamento com o cliente no
}

\section{setor de vestuários e acessórios}

\section{The quality of service and its influences on customer relationships in the clothing and accessories} sector

La calidad del servicio y sus influencias en la relación con el cliente en el sector de ropa y accesorios

\begin{abstract}
Resumo
A busca pela qualidade se tornou constante em diversas áreas, inclusive no atendimento ao cliente, pois é uma oportunidade que a empresa possui para conseguir a satisfação e retenção dos clientes, também, por meio de um relacionamento duradouro com os clientes. Objetivo da pesquisa é analisar a qualidade do atendimento e suas influencias no relacionamento com o cliente no setor de vestuários e acessórios. A metodologia da pesquisa é classificada como descritiva, quantitativa com a utilização de um questionário fechado aplicado com 219 clientes, e qualitativa com a uso de um roteiro de entrevista. Os resultados apontaram que os resultados da pesquisa demonstram que a qualidade do atendimento não influenciou no relacionamento com o cliente da empresa. Foi conclusivo que a qualidade do atendimento não tem influenciado no Relacionamento com os Clientes da Loja de roupas no Estado do Tocantins e acessórios, pois o atendimento da empresa foi avaliado de forma positiva, se enquadrando em um atendimento de qualidade.
\end{abstract}

Palavras-chave: Cliente; Atendimento; Qualidade; Relacionamento.

\begin{abstract}
The search for quality has become constant in several areas, including customer service, as it is an opportunity that the company has to achieve customer satisfaction and retention, also, through a lasting relationship with customers. The objective of the research is to analyze the quality of the service and its influences on the relationship with the customer in the clothing and accessories sector. The research methodology is classified as descriptive, quantitative with the use of a closed questionnaire applied to 219 clients, and qualitative with the use of an interview script. The results showed that the results of the research demonstrate that the quality of the service did not influence the relationship with the company's client. It was conclusive that the quality of the service has not influenced the Relationship with the Customers of the Clothing Store in the State of Tocantins and accessories, as the company's service was evaluated in a positive way, framing in a quality service.
\end{abstract}

Keywords: Customer; Service; Quality; Relationship. 


\begin{abstract}
Resumen
La búsqueda de la calidad se ha convertido en una constante en varias áreas, incluida la atención al cliente, ya que es una oportunidad que tiene la empresa para lograr la satisfacción y retención del cliente, también, a través de una relación duradera con los clientes. El objetivo de la investigación es analizar la calidad del servicio y sus influencias en la relación con el cliente en el sector de la confección y complementos. La metodología de investigación se clasifica en descriptiva, cuantitativa con el uso de un cuestionario cerrado aplicado a 219 clientes y cualitativa con el uso de un guión de entrevista. Los resultados mostraron que los resultados de la investigación demuestran que la calidad del servicio no influyó en la relación con el cliente de la empresa. Fue concluyente que la calidad del servicio no ha influido en la Relación con Clientes de la Tienda de Ropa en el Estado de Tocantins y complementos, ya que el servicio de la empresa fue evaluado de manera positiva, enmarcando en un servicio de calidad.
\end{abstract}

Palabras clave: Cliente; Servicio; Calidad; Relación.

\title{
1. Introdução
}

Ao longo do processo para conquistar um cliente, a qualidade consiste em tudo que a empresa faz, deste modo ele adquire aquilo que lhe deseja em termos de custo, atendimento e prazo de entrega (Kalkmann, 2002).

Nesse sentido, atingir ou exceder as expectativas dos consumidores traz efeito positivo para a empresa e clientes, assim ambos ficam satisfeitos, pois superar as expectativas dos clientes, é uma estratégia usada pelas empresas que têm convicção do quão importante é, conquistá-los (Kotler \& Armstrong, 1999). Neste contexto justifica-se que o crescimento desse mercado é essencial buscar a fidelização dos clientes, sabendo que fidelizar não é só fazer com que volte a loja, vai além disso, é proporcionar satisfação de forma que ele possa recomendar, comentar e confiar em sua marca, assim é menos propício a troca pela concorrência.

Sendo assim, uma empresa que mantém uma relação satisfatória com o cliente pode se tornar uma das organizações bem-sucedidas no meio do mercado competitivo, pois os clientes fazem parte dessa contribuição para o crescimento da empresa (Kother \& Armstrong, 2003).

Deste modo se a empresa conseguir deixar seus clientes muito satisfeitos, por consequência eles produzem diversos benefícios para a empresa. Pois, clientes satisfeitos são menos sensíveis aos preços, falam bem da empresa e de seus produtos a outras pessoas, fazendo com que a quantidade de clientes da empresa cresça e permanece fiéis por um período mais longo (Kother \&Armstrong, 2003).

E para que as empresas consigam essa fidelidade é usado o marketing de relacionamento, sabendo que é um processo para identificar e agregar valores aos clientes, assim compartilhando seus benefícios durante a parceria que adquiriu no decorrer do tempo com a empresa. Isso envolve a compreensão e colaboração entre fornecedores e clientes na divulgação da boa imagem da empresa (Gordon, 2002).

Dessa maneira empresas que implantam ações de marketing de relacionamento com o cliente, elas não têm aquele contato somente comercial, mas sim um relacionamento mais próximo e afetivo, assim adquirem laços forte e os clientes se tornam fieis (Kotler, 2000).

Dessa forma a problemática se norteia-se: que maneira a qualidade do atendimento influencia no relacionamento com o cliente no setor de vestuários e acessórios? Diante do que foi exposto esse artigo têm como objetivo analisar a qualidade do atendimento e suas influencias no relacionamento com o cliente no setor de vestuários e acessórios.

\section{Referencial Teórico}

\subsection{Qualidade: Principais conceitos}

Gomes (2004) completa dizendo que qualidade se consiste universalmente como algo que afeta a vida das organizações e dos clientes de forma positiva. 
Em relação ao significado da qualidade, Leite (2019) afirma que é muito amplo, pois ela pode ser interpretada de diversos modos, ou seja, ela pode corresponder a uma busca da satisfação, a excelência e a fidelização, agregando valores aos produtos e serviços adquiridos e destinados.

Sob este enfoque, segundo Vergueiro (2002) muitas pessoas considera a qualidade como algo que produz satisfação, que está ligado ao um preço justo, um produto que funciona de modo correto e a um serviço que foi prestado segundo as expectativas do cliente.

Nesse sentido Bezerra (2015) afirma que a qualidade tem como foco alcançar a satisfação dos clientes, através de melhorias constantes do que é oferecido pela empresa, assim é baseado em 10 princípios na Figura 1 - Os 10 Princípios da qualidade, demonstrada na próxima página.

Figura 1 - Os 10 Princípios da Qualidade.

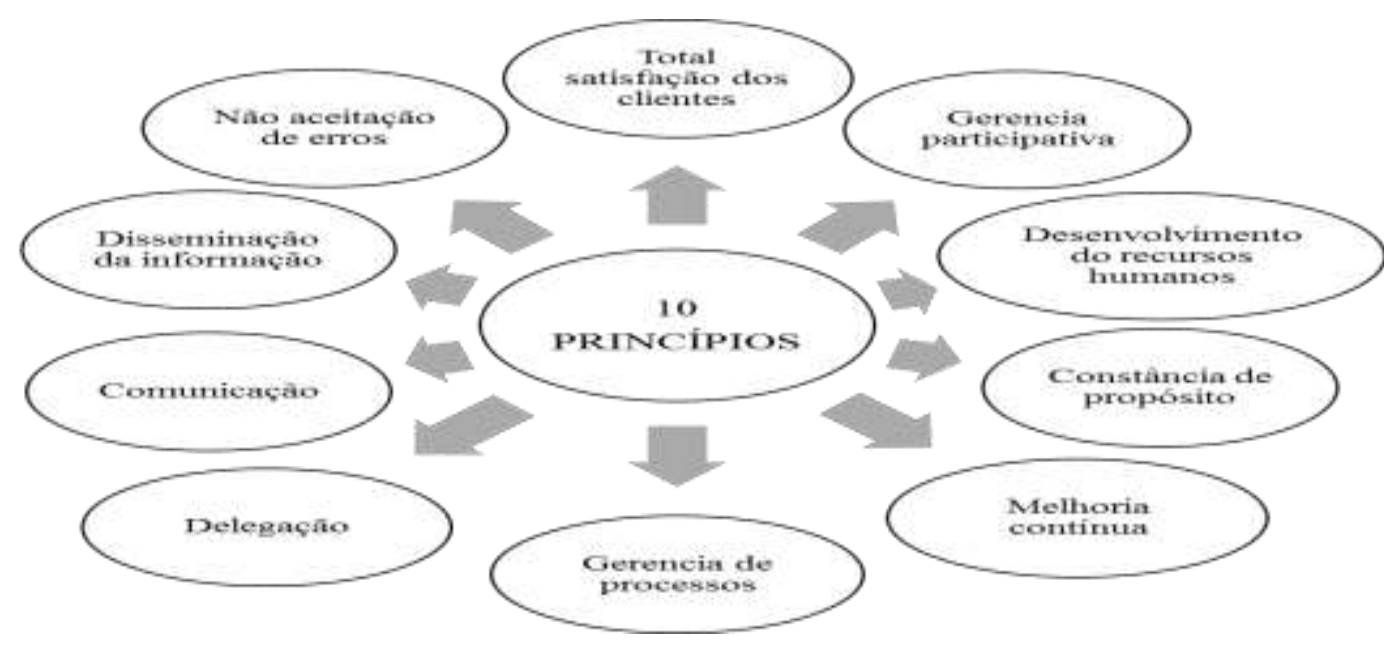

Fonte: Adaptado de Bezerra (2015)

De acordo com esses princípios, é notado que a preferência do consumidor se torna o principal foco da qualidade, assim fazendo com que a produtividade e o olhar competitivo da empresa se amplie de forma conjunta, deste modo se mantendo no mercado e conseguindo se destacar em meio a concorrência (Bezerra, 2015).

Portanto, logo a seguir será abordado sobre a qualidade do serviço dos colaboradores aos seus clientes.

\subsubsection{Qualidade de serviço}

De acordo com os principais conceitos da qualidade de serviço, Gianesi e Correira (1996) afirma que deve ser considerado as expectativas e as necessidades dos clientes e apresentar um instrumento de operação de serviço ágio em curto e longo prazo, para que possa ter uma boa avaliação na qualidade do serviço.

Assim para ter uma avaliação positiva deve-se seguir os princípios da qualidade de serviço que são o acesso a empresa, boa comunicação, funcionários capacitados, empresa com credibilidade, colaboradores receptivos e que transmite confiança, segurança no serviço e a compreensão do cliente (Kotler, 2006).

Já Farias (2003) propõe um Modelo com Cinco GAPs explicando que são desarmonias ocorrentes dentro da empresa, e entre os clientes e a organização, e provocam uma má qualidade do serviço prestado, conforme apresentado no Quadro 1Modelo dos Cincos GAPs apresentado abaixo. 
Quadro 1 - Modelo dos Cincos GAPs.

\begin{tabular}{|c|l|}
\hline MODELO & \multicolumn{1}{c|}{ CARACTERÍSTICAS } \\
\hline GAP 1 & $\begin{array}{l}\text { É a diferença entre o serviço prestado e o serviço que o cliente esperava ter recebido. } \\
\text { É causado quando não se consegue identificar e alcançar a expectativa do seu consumidor. }\end{array}$ \\
\hline GAP 2 & $\begin{array}{l}\text { É a diferença do que a gerência identificou como desejo do cliente e o efeito da qualidade do seu } \\
\text { serviço. } \\
\text { É a falta de instrumentos operacionais disponíveis para que os clientes possam se comunicar com a } \\
\text { empresa e as limitações de recursos causam essa falha. }\end{array}$ \\
\hline GAP 3 & $\begin{array}{l}\text { É a dessemelhança entre as características da qualidade do serviço e o serviço que realmente foi } \\
\text { entregue. } \\
\text { É a ausência de conhecimento e habilidades dos empregados sobre a qualidade de um serviço. }\end{array}$ \\
\hline GAP 4 & $\begin{array}{l}\text { É a divergência entre a qualidade do serviço gerado e o que foi comunicado para o cliente. } \\
\text { É a falta de comunicação entre a empresa e o cliente e pode ter ocorrido uma divulgação de algo que a } \\
\text { empresa não pode proporcionar. }\end{array}$ \\
\hline GAP 5 & \begin{tabular}{l} 
É a somatória do GAP 1, GAP 2, GAP 3 e o GAP 4 \\
\hline
\end{tabular} \\
\hline
\end{tabular}

Fonte: Adaptado de Farias (2003).

Ainda de acordo com os Cinco GAPs de Farias (2003) é importante ressaltar que o GAP 1 pode ser corrigido essa falha, por meio de uma comunicação entre a empresa e o cliente, deste modo a empresa pode fazer uma pesquisa de mercado que irá identificar sobre as necessidades e desejos do público que ela atende; o GAP 2 então deve - se disponibilizar instrumentos operacionais e ter uma rápida resposta para os pedidos dos seus consumidores.

Nesse sentido, ele continua ressaltando que no GAP 3 para que possa corrigir o problema, a empresa deve capacitar os seus funcionários e quando houver um recrutamento deve ter o perfil que a empresa necessita. Logo em seguida implantar avaliações de desempenho do empregado, ter uma supervisão com eficiência e procurar manter um clima organizacional agradável; GAP 4 nessa situação pode ser resolvida com uma melhora na comunicação interna entre os diversos setores da empresa e consequentemente na comunicação externa.

\subsubsection{A qualidade no atendimento}

Castro (2010) verificou as ocorrências sobre o atendimento ser algo tão criticado que, este elemento passa a ser um diferencial competitivo no mercado. A empresa que tem um atendimento de qualidade com o seu cliente, com educação, profissionalismo, demonstrando interesse em atender às necessidades dos clientes, estão em um nível elevado comparado aos seus concorrentes. Isso porque as pessoas não estão habituadas a serem bem tratadas, e quando isto acontece, elas dão o favoritismo para quem lhes deu esse atendimento excelente.

Sendo assim, o atendimento ao cliente é um dos aspectos mais importantes, pois conquistar os clientes é o principal objetivo do negócio. Todo negócio deve se preocupar com a opinião do cliente, sabendo que só permanecerá no mercado de trabalho se o cliente estiver disposto a continuar adquirindo os seus produtos ou serviços (Chiavenato, 2007).

Segundo Walker (19910, existe dez mandamentos do bom atendimento conforme serão apresentados no Quadro 2 Os Dez Mandamentos do Bom Atendimento. 
Quadro 2 - Os Dez Mandamentos do Bom Atendimento.

\begin{tabular}{|c|c|}
\hline MANDAMENTO & CONCEITOS \\
\hline Atenda bem todas as pessoas & $\begin{array}{l}\text { Evite passar uma primeira má impressão ao cliente. Sorria, seja educado, gentil } \\
\text { e sempre utilize o tratamento Senhor e Senhora. }\end{array}$ \\
\hline Atenda de imediato & $\begin{array}{l}\text { Não deixe o cliente esperando sem avisar antes, use a frase Por favor, aguarde } \\
\text { um momento, logo irei atendê-lo }(a) \text {...é uma forma de pedir que tenha um } \\
\text { pouco de paciências, mas evite que ele fique esperando por muito temo e } \\
\text { lembre-se também que devesse ter não só rapidez, mas qualidade no } \\
\text { atendimento. }\end{array}$ \\
\hline Dê atenção ao cliente & $\begin{array}{l}\text { Deve-se dá a devida atenção a todas as exigências do cliente, faça com que ele } \\
\text { perceba o quanto você está disposto a atender sua necessidade. }\end{array}$ \\
\hline Mostre boa vontade & $\begin{array}{l}\text { Procure saber nos detalhes se o cliente está a confortável com o atendimento, } \\
\text { deste modo encontre a melhor forma que ele prefira que seja tratado, ele precisa } \\
\text { saber que a empresa está interessada em satisfazê-lo. }\end{array}$ \\
\hline Preste orientação segura & $\begin{array}{l}\text { Primeiro identifique qual é a necessidade do cliente e logo em seguida o oriente, } \\
\text { mas o atendente deve ter segurança no que está orientando o cliente. Caso não } \\
\text { tenha essa segurança, procure alguém que possa ajudá-lo a resolver. }\end{array}$ \\
\hline Utilize vocabulário do cotidiano & $\begin{array}{l}\text { O cliente deve entender suas orientações, então deve se utilizar palavras de fácil } \\
\text { entendimento e sempre utilizando vocabulário de maneira formal. }\end{array}$ \\
\hline Não dê ordens & $\begin{array}{l}\text { Ao se comunicar com o cliente, peça e não de ordens pois eles não gostam de } \\
\text { ser mandados. Como por exemplo, ao invés de falar entre na fila, troque para } \\
\text { por favor, aguarde na fila. }\end{array}$ \\
\hline Não discuta com o cliente & $\begin{array}{l}\text { Ganhar uma discussão só trará malefícios para a empresa, pois perderá clientes, } \\
\text { então não leve para o lado pessoal as reclamações do cliente. Ouça o que ele } \\
\text { tem a dizer sem interrompê-lo, trate com paciência e calma. Se não resolver, } \\
\text { dirigia-o para o Gerente da empresa. }\end{array}$ \\
\hline Fale a verdade & $\begin{array}{l}\text { A confiança do cliente com a empresa é essencial, por isso trate-o sempre com } \\
\text { honestidade, mesmo que seja para assumir uma falha sua. }\end{array}$ \\
\hline Crie e sugira soluções & $\begin{array}{l}\text { A sua opinião pode melhorar a forma de como a empresa está trabalhando, de } \\
\text { sugestões criativas de melhoria no atendimento. }\end{array}$ \\
\hline
\end{tabular}

Fonte: Adaptado de Walker (1991).

Para conquistar mercados e manter um bom relacionamento com o cliente, as organizações devem atender seus consumidores com bom desempenho e eficiência, pois a qualidade contribui para a conquista da satisfação dos clientes, e quando é citado como ter uma qualidade no atendimento, como foi discorrido no quadro mostrado anteriormente, pode-se notar que ela está diretamente relacionada a busca não só da satisfação, mas de como adquirir um bom relacionamento com o cliente (Silva, 2016). Desse modo o tópico a seguir será discorrido sobre o relacionamento com o cliente.

\subsection{Relacionamento com os clientes}

Para conseguir clientes deve se vender aquilo que eles precisam, e para descobrir o que eles querem tem que conhecer o seu público alvo, sabendo suas vontades, necessidades e tendências de compra. É preciso que execute uma abordagem que possa entrar em contado com o cliente, que o resultado proceda de forma que a empresa possa conseguir de alguma forma ter um relacionamento com o cliente (Albrecht \& Bradford, 1992).

Nos pensamentos de Batista (2010), o serviço de atendimento ao consumidor cumpre um importante papel no processo de relacionamento e satisfação constante dos clientes. A importância de um relacionamento alternativo e qualificado 
enrijece a ideia do quanto o encontro da empresa com o consumidor influencia na compreensão do cliente, em relação ao serviço prestado e principalmente na imagem da empresa.

Logo em seguida Kotler (2006) complementa dizendo que maximizar o valor do cliente, significa que deve ser cultivado um relacionamento de longo prazo com o mesmo. Ou seja é proporcionar ao cliente o comprometimento de que ele é importante para empresa, que não é apenas um cliente, mas alguém que está em procura de valores que efetive sua integridade.

Assim, pode se ver que está é a nova era da empresas, com o relacionamento centrado no cliente, pois quanto mais uma empresa investe em atendimento, maior é a eficiência de se manter firme no mercado e fornecendo dos bens e serviços esperados, satisfazendo-os de forma encantadora (Batista, 2010).

Segundo Leite (2013) deve ser evitado o máximo que for possível ter um relacionamento ao cliente insatisfeito, nesse caso é necessário começar a ter uma comunicação entre a empresa e o cliente. Lembrando que um cliente insatisfeito poderá produzir mais nove clientes insatisfeitos próximos a ele. Com isso deve-se ir atrás de suprir as necessidade e desejos dos clientes, fazendo com que em vez de perder clientes, a empresa ganhe clientes. Deste modo, será redigido no tópico abaixo os pontos a respeito de satisfação e fidelização de clientes

\subsubsection{Satisfação e fidelização do cliente}

Um dos principais meios para fidelizar o cliente é a satisfação. Na perspectiva de Gil (1997), a qualidade é procurar satisfazer os desejos e anseios do consumidor, através de um atendimento envolvendo a eficácia.

Castro (2010) afirma que é preciso que as empresas entendam que os seus colaboradores não vêm do jeito que a empresa deseja, alguns até mesmo sem experiência, e isso, pode não parecer, mas é algo bom. Pois quando eles vêm com experiências é muito mais difícil desconstruir comportamentos, postura e hábitos já foram carregados há algum tempo.

Por isso Seide (2012), aborda que as organizações devem investir recursos em treinamento dos seus colaboradores com intuito de capacita-los para desenvolver atitudes com proposito de satisfazer as necessidade, desejos e expectativa dos cliente, assim sabendo identificar o que os agrada para que possa melhorar seus serviços prestados ou produtos oferecidos, no perfil que a empresa deseja que eles trabalhem.

Em função disso Rocha e Christensen (1999) completa afirmando que, o cliente só conseguirá se manter como consumidor de determinada empresa por um longo período se ele estiver satisfeito com os produtos e serviços. E é para isso que as empresas devem utilizar a fidelização com o cliente, desenvolvendo formas para aproximar o contato com eles e assim os mantendo como consumidores fixos da empresa (Kotler \& Keller, 2006).

Nestes termos e com o mesmo pensamento Kotler (2000) define que um para um cliente estar altamente satisfeito ele tem os seguintes comportamentos: Permanece fiel por muito tempo; Compra mais de acordo com que a empresa lança novos produtos existentes; Fala favoravelmente da empresa e de seus produtos para outras pessoas; Dá menos atenção a marcas e propaganda dos concorrentes e é menos sensível ao preço; Apresenta ideias sobre produtos ou serviços à empresa; Perde menos tempo para ser atendido do que novos clientes, uma vez que já tem seus cadastros e assim permitindo ter um atendimento mais ágil.

\section{Metodologia Da Pesquisa}

\subsection{Delineamento da Pesquisa}

O presente trabalho terá como base bibliográfica, dessa forma Lakatos e Marconi (2001) aborda que o estudo bibliográfico abrange toda teoria que já foi se tornada pública em relação ao tema que será abordado, publicações em jornais, 
revistas, livros, monografias, teses e etc. Desse modo tem como finalidade fazer com que o pesquisador tenha um contato direto com tudo que foi escrito sobre determinado assunto.

Então, o desenvolvimento da pesquisa será de forma qualitativa e quantitativa, sob este enfoque, segundo Silva e Menezes (2001) tudo pode se traduzir em números, como opiniões e informações, em vista disso permite ser melhor para classificar e analisar os dados, mas para obter os resultados requer o uso de técnicas e estatísticas.

A pesquisa foi realizada por meio de um questionário estruturado com questões fechadas. O questionário foi aplicado com os clientes da Loja de roupas e acessórios no Estado do Tocantins. Os clientes responderam, de forma on-line o questionário, o qual foi disponibilizado no sistema Google Docs, sendo enviado através do aplicativo WhatsApp.

Esse trabalho será apresentado os resultados relacionados com a qualidade do atendimento e suas influencias com relacionamento com o cliente no setor de vestuário e acessórios. Os clientes foram convidados a responde cada questão, usando uma Escala Likert de cinco pontos, com as seguintes categorias: Sempre (1), Frequentemente (2), Ás vezes (3), Raramente (4) e nunca (5). Em um questão as categorias foram: Muito Satisfeito (1), Satisfeito (2), Nem Satisfeito Nem Insatisfeito (3), Insatisfeito (4) e Muito Insatisfeito (5). Também teve questões somente de sim ou não.

Também foi realizado analise através de observação direta do atendimento dos colaboradores da Loja de roupas e acessórios no Estado do Tocantins com seus clientes, e uma entrevista foi realizada com o Gerente da empresa, por meio de um roteiro de entrevista estruturado com perguntas abertas. Deste modo, todos esses dados citados acima, foram coletados nos meses de Agosto de 2019 e Setembro de 2019.

De acordo com o cálculo de amostragem, com base na quantidade de clientes que frequentam a empresa por mês, foi repassado o número de em média 1200 clientes. Então foi realizado o cálculo com tamanho da população 1200 , nível de confiança $95 \%$ e margem de erro de 6\%, deste modo foi realizado o questionário com 219 clientes da Loja de roupas e acessórios no Estado do Tocantins.

\subsection{Técnica de análise dos dados}

Foram utilizadas três técnicas de analise nesse trabalho, analise de dados gráficos, entrevistas e observação direta na empresa.

Primeiro, foi realizado uma entrevista com o gerente da Loja de roupas e acessórios no Estado do Tocantins, no roteiro foi elaborado com base nos pontos abordados no referencial teórico do presente trabalho, como qualidade no atendimento, qualidade no serviço, relacionamento com o cliente, satisfação e fidelização dos clientes. A entrevista foi gravada e transcrita para realizar a análise com base nas teorias estudadas.

O Segundo passo, foi aplicado um questionário para os clientes que frequentam a empresa de vestuário e acessórios, as perguntas foram divididas em 4 pontos, o perfil do entrevistado para identificação de sexo, idade, escolaridade, logo em seguida foi elaborada questões para identificar o perfil do cliente da empresa, com embasamento na autora Bretzke (2010).

Após identificar, vamos para a verificação da maneira que o atendimento é feito pela empresa, de acordo com a teoria dos dez mandamentos do bom atendimento de Walker (1991) e por fim ver a influência do relacionamento com o cliente de acordo com Farias (2003). Esses são somente os autores principais, no decorrer da analise terá demais autores para confirmar e compara as teorias.

E para finalizar, foram feitas visitas na Loja de roupas e acessórios no Estado do Tocantins para observar os serviços da empresa, se condiz com que foi repassado, obtendo um contato mais direto da realidade, assim podendo presenciar comportamentos que podem acontecer no dia - a - dia da empresa. As observações foram realizadas de forma discreta em dias 
alternados e em diferentes horários, para que não houvesse constrangimento com os colaboradores e deste modo não influenciando na execução de suas tarefas, com a realização de anotações de dados relevantes a pesquisa.

\section{Resultados e Discussões}

A presente pesquisa é realizada na Loja de roupas e acessórios no Estado do Tocantins que abriu a sua primeira loja no ano de 1990, sendo uma empresa familiar. Hoje tem uma franquia de mais de 60 lojas espalhadas pelo Brasil, incluindo os estados do Goiás, Bahia, Mato Grosso, Pará, Maranhão e Tocantins.

Foi percebido pelo fundador que mesmo sendo um estado novo, o Tocantins teria um potencial de crescimento em expansão e financeiramente, por esse motivo foi implantado várias lojas por diversos municípios incluindo Dianópolis em 2009, o primeiro gerente da loja tomou a gestão por 10 anos e só em 2019 que houve troca na gerencia.

Atualmente, a loja de roupas e acessórios é composta por um casal assumindo a gerência, sendo que na gestão passada também era representado por um casal, e para completar a área de gestão é composto por um subgerente. A empresa possui ainda um auxiliar administrativo e um supervisor.

Para o setor de vendas são compostos por sete vendedores e no domínio do caixa são três colaboradores, um na parte de cobranças e dois responsáveis pelo depósito. Assim a empresa possui um total de 18 colaboradores compondo uma das maiores lojas do município no qual foi realizada a pesquisa.

\subsection{O perfil dos clientes da empresa}

Para poder colocar todas as estratégias do marketing de relacionamento em pratica, primeiramente a empresa deve conhecer melhor o perfil do seu cliente e Bretzke (2010) e demais autores tem teorias que vão ajudar a identificar o perfil do cliente da Loja de roupas e acessórios no Estado do Tocantins, que será discorrido nos tópicos a seguir com os resultados dos questionários aplicado aos clientes.

\subsubsection{Sexo}

De acordo com as informações coletadas, a maior parte do público da empresa é identificado pelo público feminino com percentual de $68,0 \%$ e com $30,1 \%$ que equivale ao público masculino e na alternativa de outros para público de outros gêneros foi detectado a porcentagem de $1,8 \%$.

Figura 2 - Sexo dos clientes.

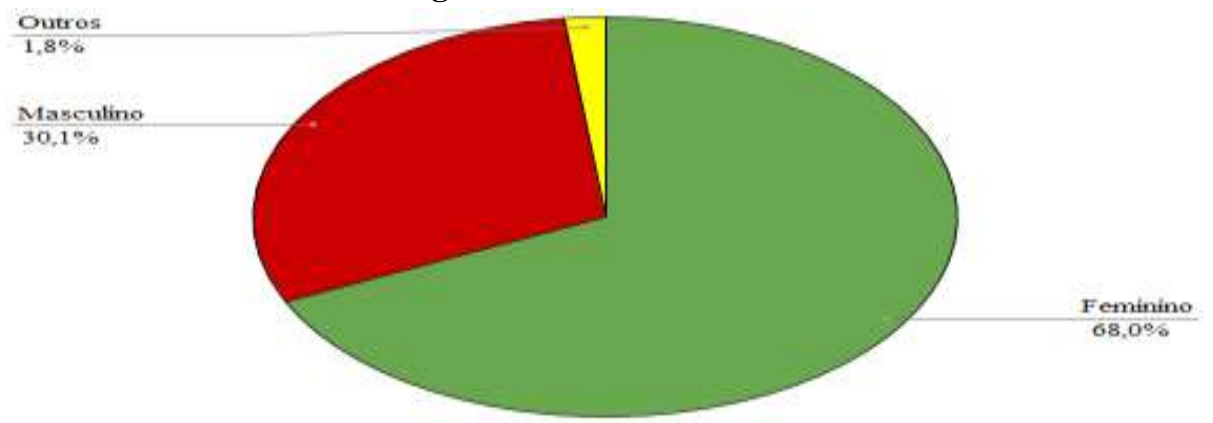

Fonte: Elaborado pelos autores com os dados coletados. 


\subsubsection{Faixa etária}

Diante dos dados coletados com os cliente da empresa que trabalha com vestuários e acessórios, a faixa etária é caracterizada por $44,7 \%$ de pessoas entre 18 a 25 anos, sendo que $28,3 \%$ possuem 25 a 35 anos, bem como $16,9 \%$ corresponde os de 35 a 45 anos e para as pessoas acima de 45 anos foi identificado o índice de 10,0\%.

Figura 3 - Faixa Etária dos Clientes.

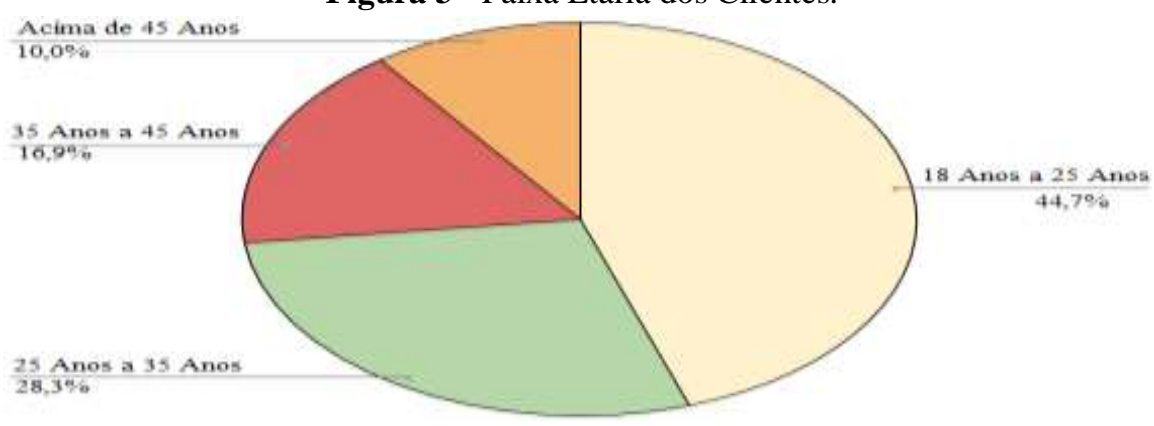

Fonte: Elaborado pelos autores com os dados coletados.

É observado que a grande parte dos respondentes correspondem a indivíduos de faixa etária entre 18 a 25 anos referindo a 44,7\%, sendo representado por quase a metade de todos clientes que responderam o questionário.

\subsubsection{Escolaridade}

De acordo está exposto na Figura 4 o nível de escolaridade não é um fator que impede que os serviços prestados pela empresa sejam usufruídos por todos. Pois, 35,2\% possuem superior incompleto, 32,4\% portam de ensino médio completo, 24,7\% tem nível superior completo, 4,1\% ensino médio incompleto, $1,8 \%$ ensino fundamental completo e $0,9 \%$ são indicado por sem escolaridade e o mesmo percentual para fundamental incompleto.

Figura 4 - Nível de escolaridade.

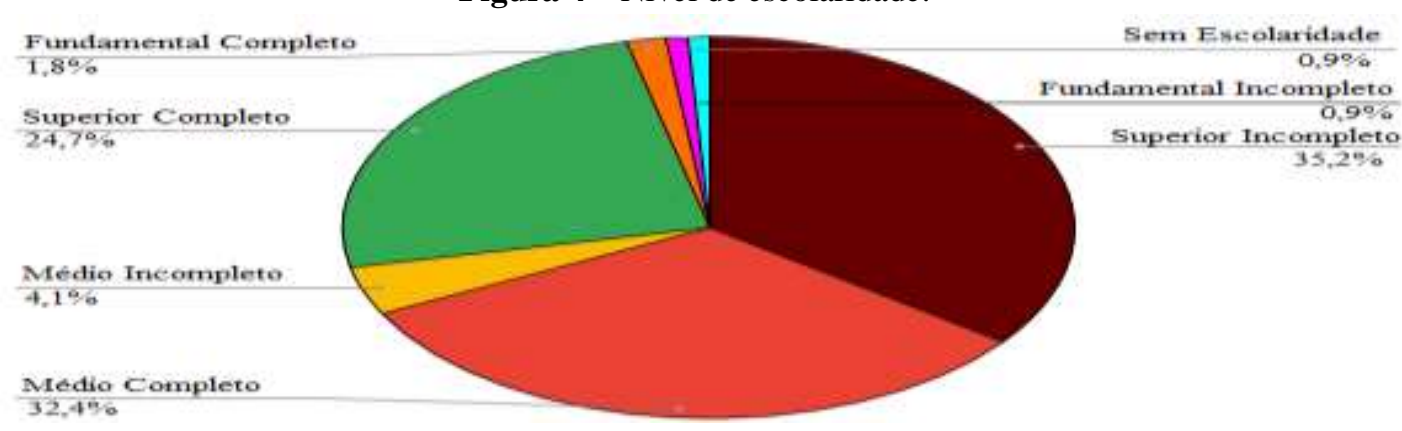

Fonte: Elaborado pelos autores com os dados coletados.

\subsubsection{Identificação do Perfil do Cliente}

Foi questionado aos clientes a frequência com que eles adquirem produtos da Loja de roupas e acessórios, e com $40,6 \%$ é representado por serem adquirido ás vezes, $23,7 \%$ adquiridos raramente, $20,1 \%$ frequentemente, $11,4 \%$ sempre e $4,1 \%$ nunca. E logo em seguida foram abordados se indicariam a empresa.

Figura 5 - Frequência que clientes adquirem produtos na loja. 
Research, Society and Development, v. 10, n. 4, e32410414288, 2021

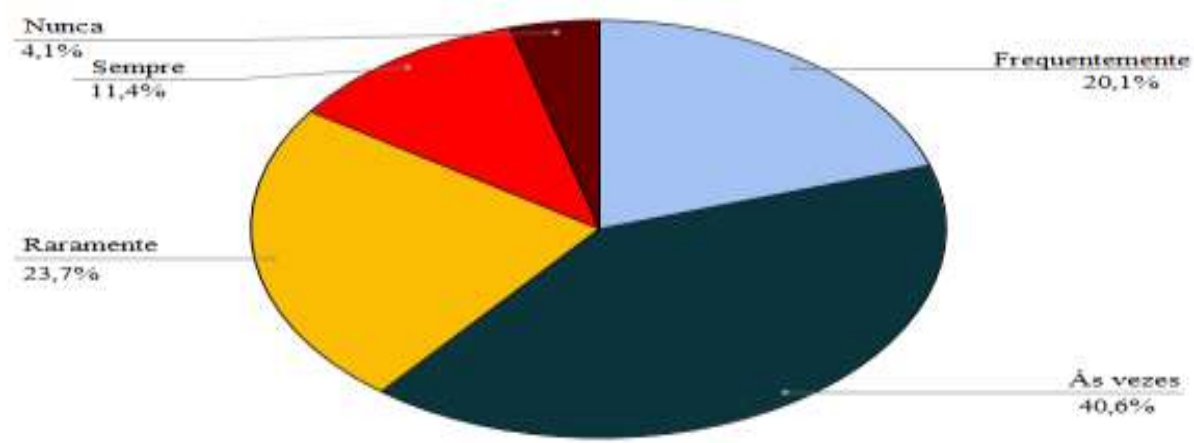

Fonte: Elaborado pelos autores com os dados coletados.

Com o questionamento, da Figura 6, obteve um resultado bastante positivo com muito mais da metade das respostas sendo SIM com 79,9\% afirmando que indicariam a empresa, alguns indecisos responderam que talvez com 16,9\% e alguns NÃO indicariam representando somente com 3,2\%. Em seguida o nível de satisfação dos serviços da empresa é avaliado.

Figura 6 - Indicação da empresa.

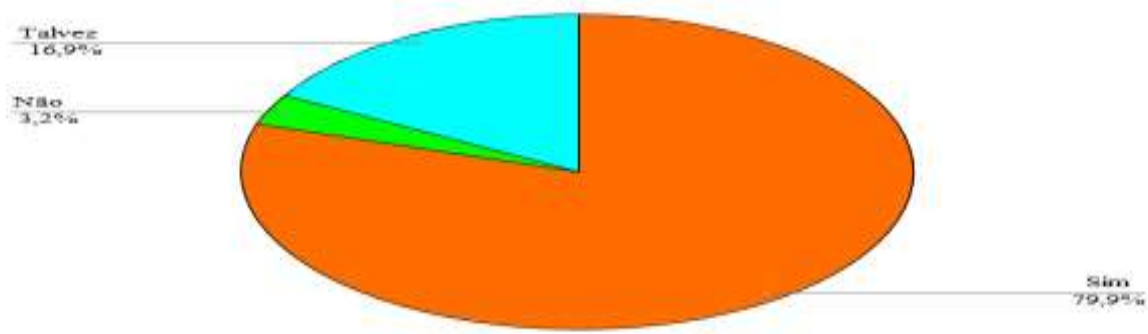

Fonte: Elaborado pelos autores com os dados coletados.

Em relação ao nível de satisfação dos serviços prestados pela empresa, Figura 7, houve um resultado favorável com $61,6 \%$ considerando satisfeitos, $18,3 \%$ se encontrem muito satisfeito, $16,4 \%$ nem satisfeitos e nem insatisfeitos, $2,7 \%$ insatisfeitos e $0,9 \%$ muito insatisfeito.

Figura 7 - Qual o nível de satisfação com os serviços da empresa.

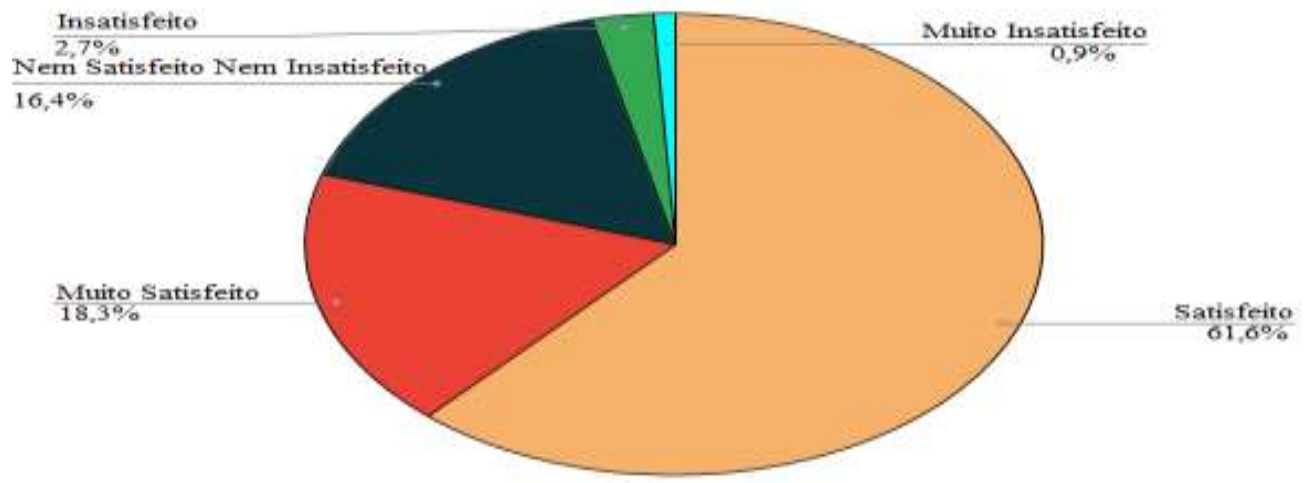

Fonte: Elaborado pelos autores com os dados coletados.

Sobre alcançar a satisfação o Gerente 1 da empresa diz "se existisse uma metodologia especifica era bom demais para os comerciantes, descobrir como satisfazer o percentual de $100 \%$ dos clientes, dificilmente a gente vai conseguir alcançar esse grau de perfeição". E ele continua dizendo como faz para fidelizar os clientes satisfeitos: 
Research, Society and Development, v. 10, n. 4, e32410414288, 2021

(CC BY 4.0) | ISSN 2525-3409 | DOI: http://dx.doi.org/10.33448/rsd-v10i4.14288

O crediário é uma forma muito boa de fidelização por que o cliente ele quer comprar mais dificilmente ele vem com o valor à vista, dá uma compra de mil reais por exemplo e as vezes não tem aquele valor total e a gente sabe que a nossa população a maioria da renda perca pita dela é um salário mínimo, um salário e meio, então não vai tirar o salário do mês para poder pagar sua compra. Então o crediário é uma forma de fidelização, eles vem compram, parcelam em dez vezes, paga um aparcela de vinte, cinquenta reais, cem reais, vão andar bem e vão conseguir honrar o compromisso. Outra forma de fidelização são os descontos que conseguimos o mesmo do crediário igual o á vista, e aquele cliente que compra e paga de forma antecipada ou paga sempre certinho e tem uma movimentação grande com a loja ou seja está usando de reciprocidade ao longo do tempo ele ganha dez por cento de desconto em qualquer forma de parcelamento que ele tem com a loja né (Gerente 1).

É observado que em relação a frequência que adquirem os produtos $4,1 \%$ responderam nunca, esse percentual representa os clientes que não chegam a finalizar suas compras, um percentual pequeno, mas que deve ser trabalhado pela empresa para a conquista desses clientes.

Para conquista de novo clientes, o Gerente 1 abordou a seguinte estratégia:

Como estratégia agora estamos utilizando dez por cento de desconto no crediário para qualquer forma de parcelamento na sua primeira compra, então a Priscilla veio aqui na loja e abriu o crediário, na primeira compra da Priscilla ela vai ter dez por cento de desconto é a forma de começarmos atrair um pouquinho mais de clientes.

Pode reparar que a estratégia que estão utilizando é somente para clientes que realizarem compras no crediário, há clientes que preferem efetuar suas compras somente à vista, e com eles da mesma forma deve ser utilizado estratégias de conquista. O relacionamento com o cliente pode ser uma tática pra ser utilizada, Marques (2006) explica que um bom relacionamento com o cliente é a chave para o sucesso da sua empresa, assim para poder ampliar os negócios da empresa, deve buscar conquistar novos clientes, reconquistas os atuais e se esforçar ao máximo para diminuir a perda destes.

Com a coleta de dados dessas três questões pode-se identificar de acordo com a teoria de Bretzke (2010) que os clientes da Loja de roupas e acessórios se definem no perfil de clientes fiéis, pois são os clientes que se encontram satisfeitos com os serviços oferecidos pela empresa, mas não concretam seu maior volume de compra. Já que boa parte só adquire produtos ás vezes 40,6\%, mas 79,9\% indicaria a empresa para amigos e conhecidos e 61,6\% se encontram satisfeitos com os serviços oferecidos.

\subsection{Maneiras que o atendimento é oferecido}

Machado (2013) completa dizendo que os clientes tem um grande poder de escolha, então, as empresas que realmente colocarem a teoria da qualidade do atendimento em prática, vão criar mais condições de se manterem vivas no mercado.

Nesse tópico é abordado sobre a maneira que o atendimento é oferecido na empresa do setor de vestuário e acessórios que foi escolhida para presente pesquisa, isso relacionando com a principal teoria dos dez mandamentos do bom atendimento realizada por Walker (1991).

Os resultados Figura 8 abaixo se referem a Loja de roupas e acessórios ter um atendimento de qualidade 47,9\% avaliam que sempre apresenta um bom atendimento, 32,9\% já ver que é algo que frequentemente acontece, 16,4\% descorda observando que ás vezes é presente esse atendimento de qualidade, somente 1,8\% acham que nunca tem, e $0,9 \%$ presencia esse atendimento raramente na empresa.

Figura 8 - A Empresa possui atendimento de qualidade. 
Research, Society and Development, v. 10, n. 4, e32410414288, 2021

(CC BY 4.0) | ISSN 2525-3409 | DOI: http://dx.doi.org/10.33448/rsd-v10i4.14288

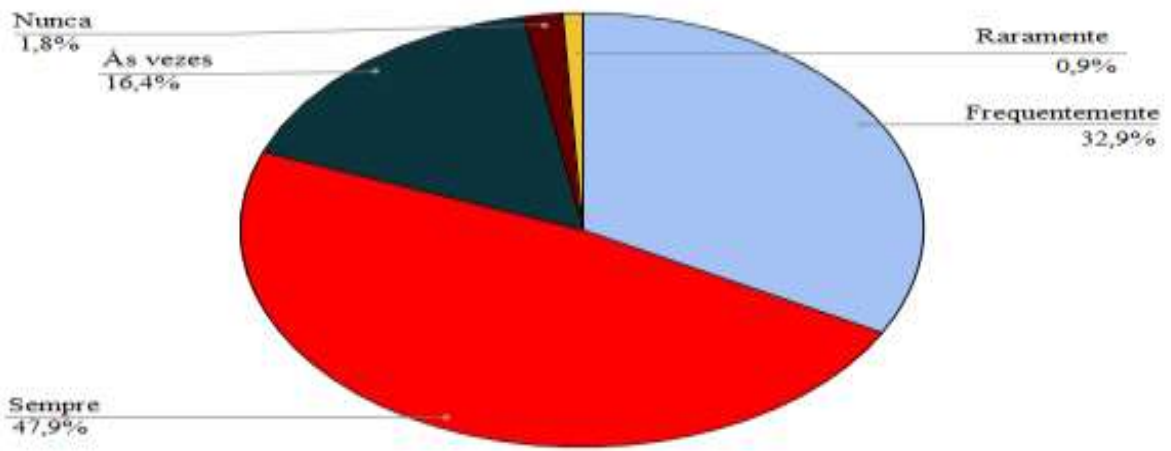

Fonte: Elaborado pelos autores com os dados coletados.

Já na Figura 9, apresentada na próxima página, em relação a agilidade dos serviços prestados, a empresa se saiu muito bem com 50,7\% dos respondentes afirmando que sempre são atendidos com rapidez, 26,0\% frequentemente acontece isso, $20,1 \%$ ressaltam que ás vezes, $1,8 \%$ raramente e $1,8 \%$ nunca.

Figura 9 - A empresa atende com rapidez.

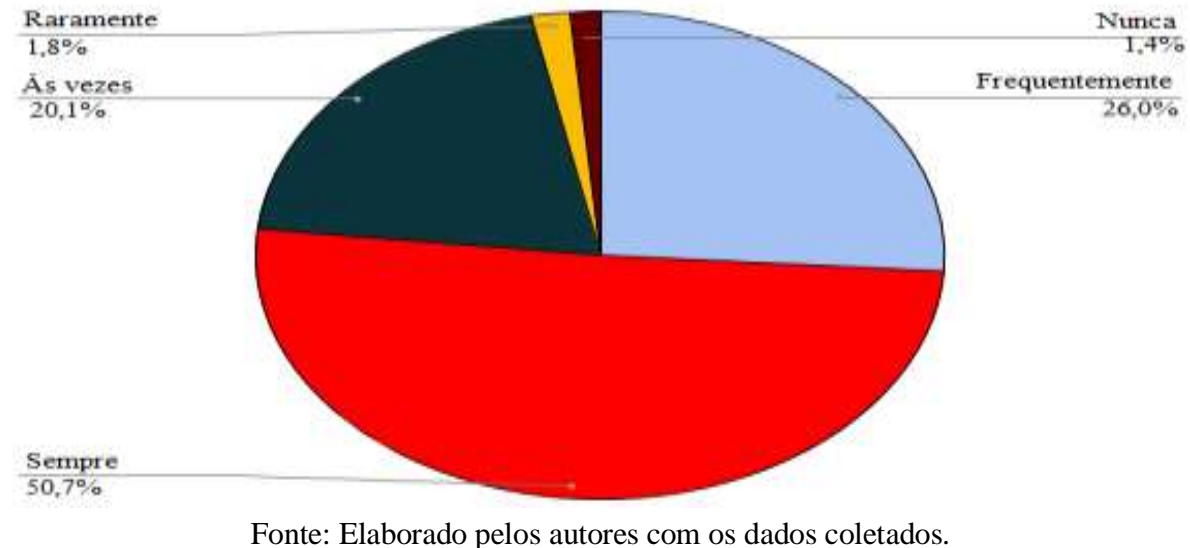

Em conformidade com o Figura 10 a qual demonstra que 47,9\% concordam que os colaboradores sempre transmitem confiança durante o atendimento, 32,4\% afirmam que isso acontece frequentemente, 15,5\% presenciou somente ás vezes, $2,3 \%$ raramente presenciou essa confiança em suas compras e 1,8\% nunca obtiveram dessa experiência

Figura 10 - Colaboradores e a transmissão de confiança durante o atendimento.

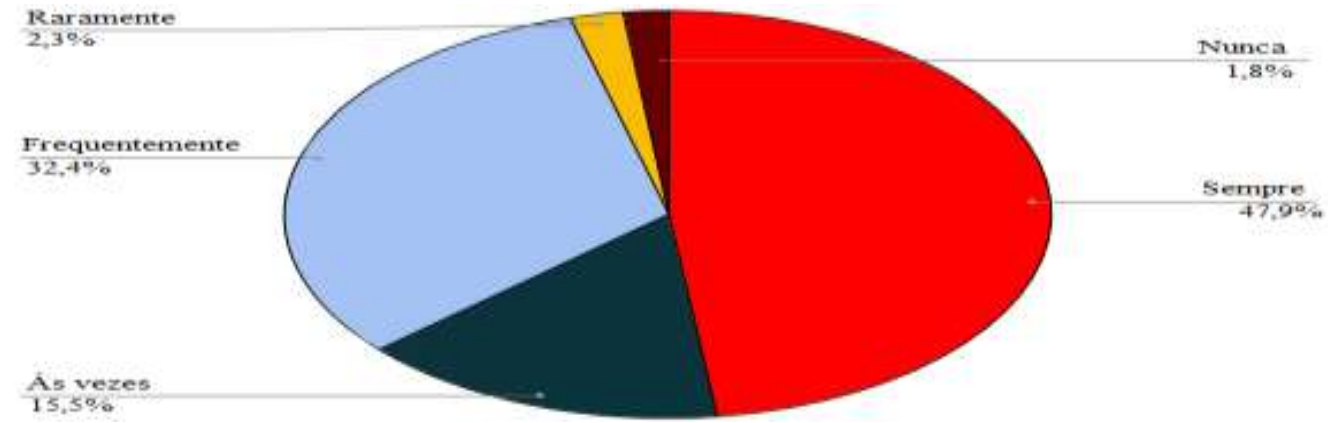

Fonte: Elaborado pelos autores com os dados coletados. 
Como demostrado na Figura 11, a metade dos respondendo representando 50,2\% responderam que sempre é recebido pelos colaboradores com boa vontade em atendê-los, 30,6\% somente frequentemente, ás vezes o total de 14,6\%, raramente apenas $2,7 \%$ e nunca somente $1,8 \%$.

Figura 11 - Os colaboradores mostram boa vontade em seus serviços.

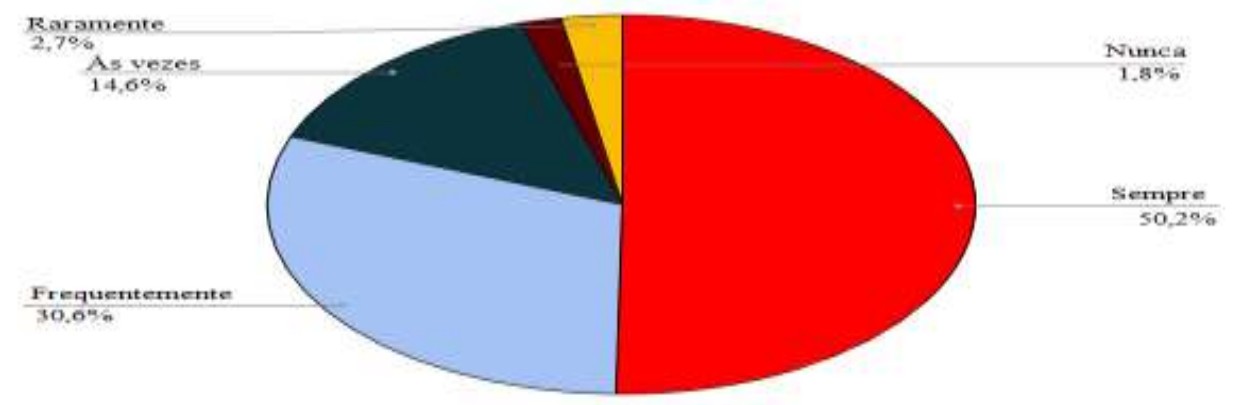

Fonte: Elaborado pelos autores com os dados coletados.

Além de boa vontade, apresentar sempre educação e respeito ao atender os clientes, conforme apresentado na Figura 12.

Figura 12 - Os colaboradores atendem com educação e respeito.

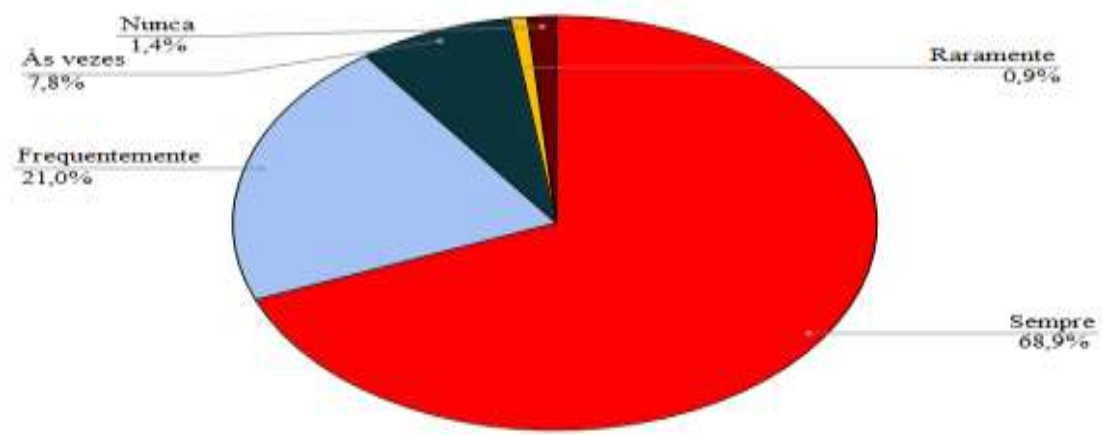

Fonte: Elaborado pelos autores com os dados coletados.

A Figura 12 apresenta o respeito e educação a empresa tem se apresentado muito bem, já que mais da metade com $68,9 \%$ concordaram que sempre são bem tratados, $21,0 \%$ frequentemente, $7,8 \%$ ás vezes, 1,4\% nunca e $0,9 \%$ raramente.

Para avaliar a maneira que a empresa Loja de roupas e acessórios está oferecendo o atendimento aos clientes, através desses resultados acima podemos analisar que tem um atendimento de qualidade com o maior percentual de 47,9\% concordando que sempre realiza essa qualidade em seus serviços prestados diante os clientes da empresa.

Confirmando o resultado positivo na pesquisa o gerente 1 ressalta quanto é importante um bom atendimento para a empresa: "O mais importante no atendimento ao cliente, é a valorização da pessoa do cliente né, quando o cliente vem adquirir um produto, ele vem adquirir um bom atendimento" (Gerente 1).

Sobre esse mesmo assunto o Gerente 1 continua afirmando, "Então conseguindo de alguma forma suprir as necessidades do cliente com um excelente atendimento e cuidado especialmente também do pós venda que é muito importante, a gente preza muito por isso".

Em relação a rapidez do atendimento oferecido, verificamos que 50,7\% reconhece que os serviços são feitos com rapidez, mas tem que atentar aos $20,1 \%$ que só presenciaram esse atendimento ágio somente ás vezes. 
É destacado pelo gerente 1 sobre "a observação, que mesmo nos dias de pico, onde existem muitos clientes na loja, estar sempre recebendo os clientes, independente de um vendedor ou vendera está atendendo uma cliente, duas clientes, três clientes."

Diante dessa declaração é identificado que a empresa usa orientações de um colaborador atender mais de um cliente ao mesmo tempo para o mesmo não ficar esperando e desse modo faz com que sejam atendidos com rapidez.

$\mathrm{Na}$ questão a respeito de transmitir segurança no serviço prestado, a empresa se saiu com um índice bom sendo representado por 47,9\% respondendo sempre. Para a demonstração de boa vontade ao atender os clientes 50,2\% representando a metade dos respondentes concordam que sempre e com isso demonstra que a empresa tem colaboradores que se esforçam na execução dos seus serviços. E fechou com chave de ouro com mais da metade representando um percentual de $68,9 \%$ são sempre tratados com educação e respeito.

Segundo as capacitações que a empresa realiza com os clientes, o gerente 1 diz o seguinte:

"Nós estamos de alguma forma influenciando os colaboradores, na gestão passada por exemplo já houve curso do SEBRAE que os colaboradores participaram, houve livros de qualidade no atendimento que os colaboradores foram de certa forma foram direcionados a estarem comprando para melhorar qualidade no atendimento. Mas infelizmente hoje a gente não consegue aplicar com tanta frequência como nós gostaríamos né, mas vez ou outra estamos buscando ter capacitação" (Gerente 1).

Mesmo com as capacitações não acontecendo de forma frequente na empresa, a mesma obteve resultados positivos, mas é essencial que faça com mais frequência para corrigir as falhas, já que foram marcados as opções de ás vezes, raramente e nunca no questionário aplicado aos clientes. O gerente 1 afirma que influencia seus colaboradores a buscar conhecimento sobre melhoria dos ser serviços.

Como gestores nós identificamos individualmente quais são as fraquezas de cada colaborador no sentido de atendimento e em reuniões de alguma forma a gente está tentado funcionar a melhorar nesses pontos né, indicando vídeos do YouTube, as vezes até como experiência de praça de mercado, a gente está de alguma forma dando algumas dicas, isso tem de alguma forma influenciado (Gerente 1).

\subsection{Fatores que influenciam no relacionamento com o cliente}

O relacionamento com o cliente faz com que eles fidelizem na empresa, com o intuito de determinar um relacionamento continuado, duradouro e satisfatório com os clientes, pretendendo aumentar a lealdade (Bretzke, 2010).

Na Figura 13, na próxima página, foi questionado se a empresa entra em contato com o cliente e nesse ponto a empresa teve uma análise negativa por $67,1 \%$ afirmaram que não teve nenhum contato e somente 32,9\% confirmaram que já entraram em contato. 
Research, Society and Development, v. 10, n. 4, e32410414288, 2021

(CC BY 4.0) | ISSN 2525-3409 | DOI: http://dx.doi.org/10.33448/rsd-v10i4.14288

Figura 13 - A empresa já entrou em contato com você além do momento da compra.

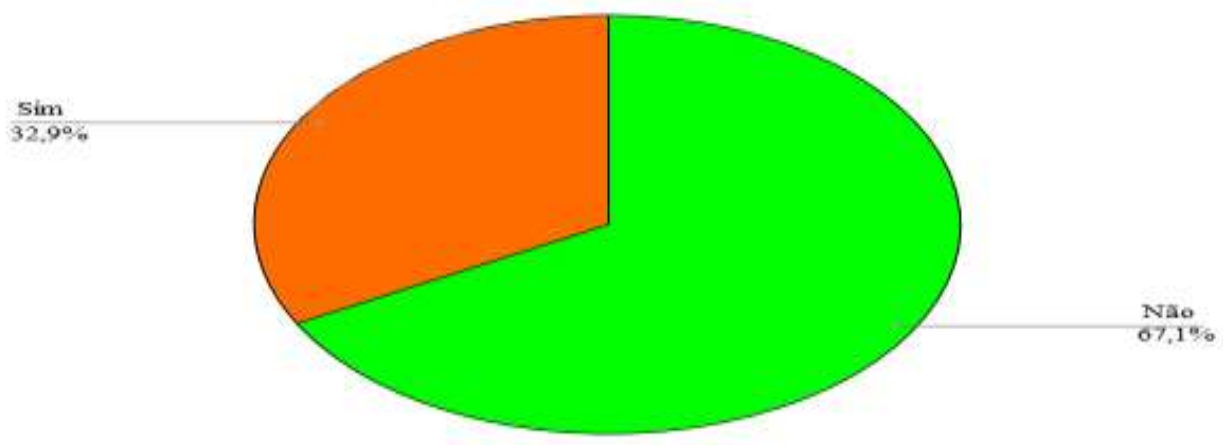

Fonte: Elaborado pelos autores com os dados coletados.

Na Figura 14, demonstra que a maior parte com $84,0 \%$ diz que nunca foram procurados pela empresa para saber suas opiniões. Somente 5,5\% confirmaram que raramente presenciaram esse ato, $4,6 \%$ ás vezes, $3,7 \%$ frequentemente e $2,3 \%$ sempre.

Figura 14 - A empresa já te procurou para saber sua opinião sobre os serviços prestados?

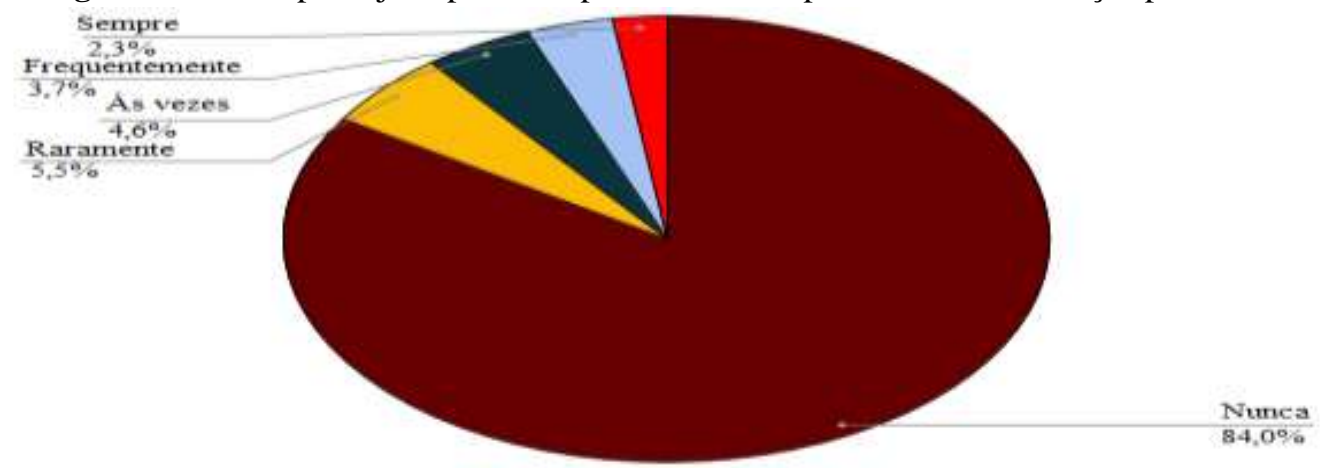

Fonte: Elaborado pelos autores com os dados coletados.

Já na Figura 15 para buscar melhor solução para os problemas dos clientes, a empresa teve uma avaliação de que $35,6 \%$ sempre resolvem da melhor maneira possível, $26,5 \%$ frequentemente, $22,8 \%$ ás vezes, $10,0 \%$ nunca e 5,0\% raramente.

Figura 15 - A empresa encaminha o cliente para melhor solução quando há um problema?

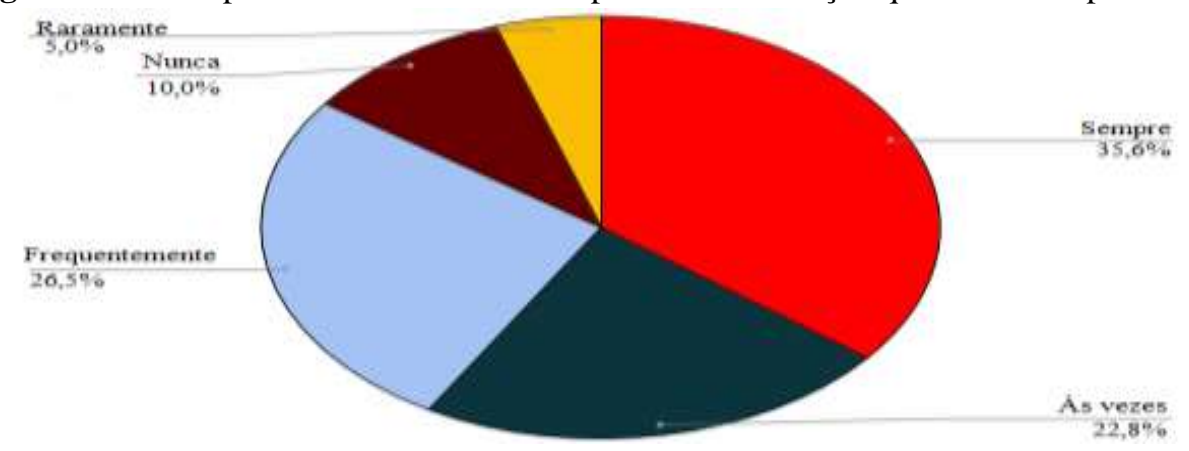

Fonte: Elaborado pelos autores com os dados coletados.

E para finalizar é verificado qual motivo leva as pessoas frequentar a Loja de roupas e acessórios, Figura 16. Dessa forma foi identificado pela empresa que $40,6 \%$ dos clientes frequentam a loja por conta dos seus produtos, $32,7 \%$ pela 
qualidade dos seus serviços, 13,2\% vão pela localização da empresa, 8,7\% por conta do preço acessível e 5,5\% pelo ambiente agradável.

Figura 16 - O que te leva a frequentar a Loja de roupas e acessórios?

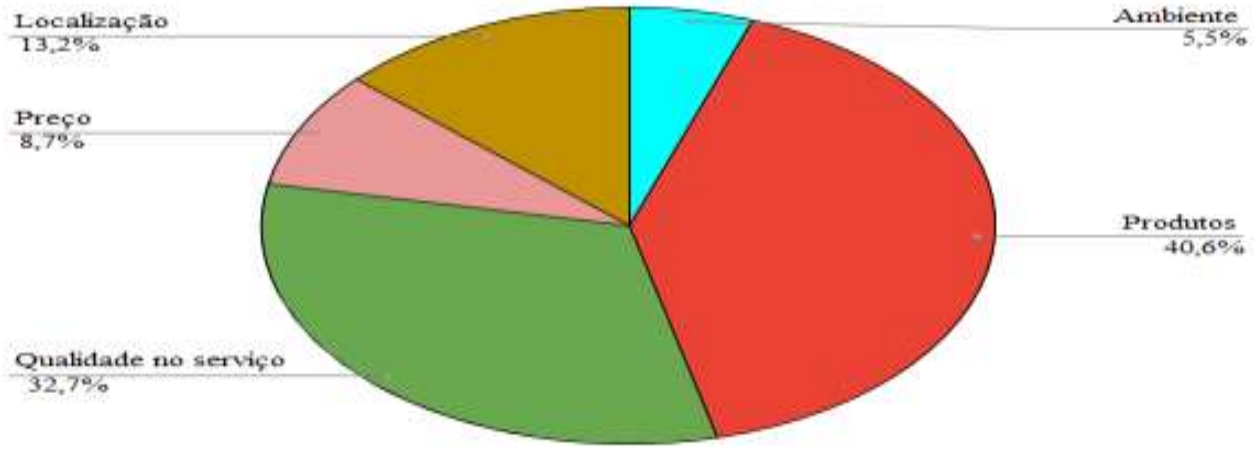

Fonte: Elaborado pelos autores com os dados coletados.

Para análise sobre relacionamento com o cliente a empresa não obteve resultados tão positivos diante os dados demonstrados. Com relação a esse assunto o Gerente 1 foi questionado em sua entrevista e deu a seguinte declaração:

Então, o tipo de relacionamento que nós temos com o cliente é basicamente ligações que a gente faz em mês ou no dia que o cliente faz aniversário ligamos para parabenizá-lo, nós tempos o bom hábito as vezes de receber o cliente né, ir lá e da aperto de mão, conhecê-lo pelo nome e chama-lo pelo nome, de alguma forma estreitar o relacionamento com aqueles clientes mais assíduos, aquele que usa de reciprocidade com a loja (Gerente 1).

Na presença dessa declaração é ressaltado que fazem ligações para os clientes ao menos uma vez ao mês, só que os resultados da pesquisa não bateram com o que foi declarado, já que mais da metade com o total de $67,1 \%$ alegou que não receberam nenhum contato com da empresa. Esse erro também pode-se identificar com o GAP 4 da teoria de Farias (2003) é a falta de comunicação entre a empresa e o cliente, nessa situação pode ser resolvida com uma melhora na comunicação interna entre os diversos setores da empresa e consequentemente na comunicação externa.

No que se diz respeito ao feedback sobre os serviços prestados da empresa, houve um índice altíssimo de reprovação, com muito mais da metade alegando que nunca foram procurados para saberem sua opinião sobre o serviço prestado, com o total de $84,0 \%$. O gerente 1 admite que há falhas nesse quesito dizendo:

... a gente entra em contato com o cliente muito especialmente no pós venda né, como nossa carteira de clientes são de clientes bem assíduos na loja, aquele cliente que as vezes vem hoje e no próximo pagamento as vezes ele já vem adquirir outro produto, o próprio cliente as vezes vem e nos traz esse feedback, as vezes nós erramos um pouco e não fazemos essas ligações. (Gerente 1)

Mas ele continua dizendo uma das suas estratégias para saber a sugestão dos clientes, que são implantadas dentro da loja.

Inclusive hoje nós temos ali no nosso caixa uma folha de sugestões onde nós colocamos a disposição do nosso setor de vendas pra que quando o cliente que não encontrou determinado produto no fim do atendimento o nosso colaborador vai lá e coloca na folha de sugestão o produto que ele não encontrou (Gerente 1).

Corroborando com esse assunto Walker (1991) afirma que a opinião pode melhorar a forma de como a empresa está trabalhando, e empresa precisa de sugestões para melhoria no atendimento. 
Sob esse enfoque o direcionamento da melhor solução para os problemas que podem acontecer com os clientes, ficou dividido entre $35,6 \%$ sempre, frequentemente $26,5 \%$ e ás vezes $22,8 \%$. Com o resultado da maioria escolhendo a opção sempre e assim sobre o melhor que pode ser feito nesses casos o gerente 1 ressalta "mas nós cuidamos muito do pós venda, né, ás vezes um produto esteve com defeito a gente cuida muito, ás vezes de estar atrelando o produto ao pós venda, questão deu problema a gente tentar resolver o mais rápido possível."

No assunto da última questão sendo uma pesquisa para saber qual o motivo que os clientes frequentam a Loja de roupas e acessórios, os maiores percentuais apresentados representam a qualidade no serviço e outro motivo são os produtos. Como obstáculos para o relacionamento com o cliente, o gerente 1 deu ênfase esses dois pontos:

A dificuldade maior é conseguir sempre acertar nos produtos, por que o cliente quando ele entra na Loja de roupas e acessórios o primeiro passo ele quer ser bem atendido né, então nós estamos batalhando, lutando para manter essa qualidade no atendimento, segundo lugar ele quer ter um bom produto, ele quer encontrar um produto de excelência, então esses são os dois principais pontos, acertar nesses principais pontos o bom atendimento e qualidade no produto né, por exemplo as vezes ele cliente quer um produto de qualidade ele vem na loja para encontrar esse produto, então é acertar sempre nos produtos.(Gerente 1)

E isso reflete na preocupação que a Loja de roupas e acessórios, pois o gerente considera como um dos maiores obstáculos e disponibilizado mais atenção a eles e com isso reflete nos resultados da pesquisa.

No assunto sobre a influência da qualidade do atendimento no relacionamento com o cliente, Batista (2010) diz, que o serviço de atendimento ao consumidor cumpre um importante papel no processo de relacionamento, pode se ver que está é a nova era da empresas, com o relacionamento centrado no cliente, pois quanto mais uma empresa investe em atendimento, maior é a eficiência de se manter firme no mercado e fornecendo dos bens e serviços esperados, satisfazendo-os de forma encantadora.

Mas, os resultados da pesquisa demonstra que a qualidade do atendimento não influenciou no relacionamento com o cliente da empresa, já que como está demonstrado na Figura 10, os clientes se encontram satisfeitos com o atendimento, mesmo sem o relacionamento por parte da empresa com os mesmo, como está explícito na Figura 15 e 16, apresentadas anteriormente.

\section{Considerações Finais}

A presente pesquisa teve como objetivo analisar a qualidade do atendimento e suas influencias no relacionamento com o cliente no setor de vestuários e acessórios, sendo escolhido a Loja de roupas e acessórios no Estado do Tocantins para realizar essa análise.

Assim Kotler e Keller (2006) corroboram sobre a fidelidade do cliente afirmando que ela proporciona à empresa uma defesa contra a concorrência. Pois essa condição acaba criando barreiras de confiança que se tornam um meio de segurança da marca, fazendo com os clientes não procurem outras empresas.

Nestes termos e com o mesmo pensamento Leite (2019) ressalta sobre os clientes querer cada vez mais qualidade nos produtos e serviços, que o importante é executar os treinamentos de maneira correta. Com isso a qualidade no atendimento esta simplificada nos indicadores da clareza, verdade e prazer.

Se tratando do Relacionamento com o Cliente, é um ponto onde a empresa tem que buscar melhorar suas falhas em comunicação, procurar saber suas opiniões, mas tem conseguido solucionar os problemas dos clientes da melhor forma e nos principais motivos da empresa ser frequentada tem se saído bem, por ser pontos onde a empresa se preocupa bastante e tem cuidado com tanta responsabilidade, sendo a qualidade dos seus serviços e produtos. 
Research, Society and Development, v. 10, n. 4, e32410414288, 2021

(CC BY 4.0) | ISSN 2525-3409 | DOI: http://dx.doi.org/10.33448/rsd-v10i4.14288

Dessa maneira, pode ser inferir que a qualidade do atendimento não tem influenciado no Relacionamento com os Clientes da Loja de roupas e acessórios no Estado do Tocantins, pois o atendimento da empresa foi avaliado de forma positiva, se enquadrando em um atendimento de qualidade, mas não tem um relacionamento com o cliente como foi demonstrado nos resultados, assim dificultando a fidelização dos mesmo.

Como Kotler (2006) afirma ser um dos prontos mais importantes do Marketing, é o foco no cliente, relacionamento com o cliente para que possa fideliza lós na empresa.

A pesquisa teve suas limitações, pois nem todos os clientes se disponibilizaram para responder a pesquisa e por falta de tempo para conseguir mais clientes, dessa maneira não teve um número maior de clientes para análise dos resultados. Como sugestão para trabalhos futuros é importante ampliar o tamanho da amostra, além disso, diminuir o grau de erro e fazer comparativo entre as empresas do mesmo grupo porém de outras cidades.

\section{Referências}

Albrecht, K. \& Bradford, L. J. (1992). Serviço com qualidade: a vantagem competitiva. São Paulo

Batista.L. (2010). SAC Relacionamento com o cliente. https://administradores.com.br/artigos/sac-relacionamento-com-o-cliente

Bezerra, F. (2015). Qualidade total: Princípios e Conceitos. https://www.portal-administracao.com/2015/02/qualidade-total-conceito-e-principios.html.

Bretzke, M. Comportamento do cliente. IN: Gestão de marketing. Saraiva.

Castro.B. (2010). Qualidade no atendimento é fundamental. https://administradores.com.br/artigos/qualidade-no-atendimento-e-fundamental.

Chiavenato, I. (2007). Empreendedorismo: dando asas ao espirito empreendedor. Saraiva.

Farias. C. A. (2003). Qualidade em serviço: modelo conceitual. http://merkatus.com.br/11_artigos/28.htm

Gianesi, I.G. \& Correia H.L. (1996). Administração Estratégica de Serviços. Atlas.

GIL, A.L. (1997). Gestão da Qualidade Empresarial. Atlas.

Gordon, I. (2002). Marketing de relacionamento: estratégias, técnicas e tecnologias para conquistar clientes e mantê-los para sempre. Futura.

Gomes, P. A (2004). Evolução do conceito de qualidade: dos bens manufaturados aos serviços de informação. Cadernos BAD.

Kalkmann, G. L.(2002). Qualidade necessária para empresas de serviços contábeis: como conquistar um selo de qualidade. Berger.

Kotler, P. (2006). Administração de Marketing. Prentice Hall do Brasil.

Kotler, P. \& Armstrong, G. (2003). Princípios de Marketing. Prentice Hall.

Kotler, P \& Keller, K.L. (2006). Administração de marketing: a Bíblia do marketing. Prentice Hall.

Lakatos, E. M. \& Marconi, M. A. (2001). Fundamentos metodologia científica. Atlas.

Leite. C. (2013). Relacionamento empresa cliente: o lucro é um. https://administradores.com.br/artigos/relacionamento-empresa-cliente-o-lucro-e-umresultado

Leite. Y. A (2019). Importância da Qualidade Total para as Organizações. https://administradores.com.br/artigos/a-importancia-da-qualidade-total-para-asorganizacoes.

Machado. C. (2013). Como agregar mais qualidade no atendimento. https://administradores.com.br/artigos/como-agregar-mais-qualidade-no-atendimento.

Marques, F. (2006). Guia prático da excelência em serviços: como conquistar clientes, aumentar os lucros e viver melhor! Nobel.

Rocha, A. \& Christhensen, C. (1999). Marketing: teoria e prática no Brasil. Atlas.

Seidi. S. (2012). Satisfação e fidelização do cliente. https://www.webartigos.com/artigos/satisfacao-e-fidelizacao-do-cliente/85460/.

Silva. E.L. \& Menezes. E.M. (2001). Metodologia da pesquisa e elaboração de dissertação. Laboratório de Ensino a Distância da UFSC.

Silva, K. M. T. (2016). A qualidade no atendimento ao cliente como fator de crescimento empresarial. Administradores.com. https://administradores.com.br/artigos/a-qualidade-no-atendimento-ao-cliente-como-fator-de-crescimento-empresarial 
Research, Society and Development, v. 10, n. 4, e32410414288, 2021

(CC BY 4.0) | ISSN 2525-3409 | DOI: http://dx.doi.org/10.33448/rsd-v10i4.14288

Silva. M. (2014). Relacionamento com o cliente: um verdadeiro casamento. https://administradores.com.br/artigos/relacionamento-com-o-cliente-umverdadeiro-casamento

Urbini. V. (2016). A importância de um bom relacionamento com clientes. https://administradores.com.br/artigos/a-importancia-de-um-bom-relacionamentocom-clientes

Vergueiro, W. (2002). Qualidade de Serviços. Atlas.

Walker, D. O (1991). Cliente em primeiro lugar: O atendimento e a satisfação do cliente como uma arma poderosa de fidelidade e vendas. Makron. 